\title{
The Choice of Codes among Santri in Communication THROUGH FACEBOOK
}

\author{
Eka Susylowati \\ English Department, Universitas Surakarta \\ esusylowati@gmail.com
}

\begin{abstract}
The era of modernization of social media has always been associated with teenagers, especially those on Facebook. This social media can be used as a medium to show their existence. The language used for communication interactions varies. The purpose of this study is to identify the choice of language codes used by students in the Islamic Modern Assalaam Islamic Boarding School in Indonesia in their communication interactions. This research is a qualitative in nature. The data under investigation are students' conversations on Facebook, which are particularly related to the choice of codes. Data collection includes observation, field notes, and interviews. This research analysis employs the components of the Hymes (SPEAKING) speech. The research results demonstrate that the choice of language codes used by students to communicate in social media involves Indonesian, Arabic, English, and Javanese. The development of technology can make communication effective for students. Besides, that can drive the changes in behavior and language they use. The significance of this research is that there are bilingualism/multilingualism phenomena through the use of Indonesian, Arabic, and English, which is proven not to shift the local language (Javanese), let alone destroying local language as a mother tongue.
\end{abstract}

Keywords: choice of codes, santri community, facebook

\section{INTRODUCTION}

Islamic boarding school has its own plus value, compared to common public education because the environment in Islamic boarding school, known as pesantren, puts equal emphasis between formal education material and diniyah material or deeper religion. Pesantren is a traditional Islamic education dormitory where students live together and study under the guidance of a (more) teacher, better known as 'Kyai'. The dormitory for santri is in a pesantren environment where the Kyai resides, which also provides a mosque for worship, a room for study, and some sections for religious activities. Pesantren is a favorite because religious teachers and clerics have provided their emotional, intellectual, and spiritual faith as well as knowledge so that they are able to face the era of modernization and are taught Islamic values which are bound to 'rahmatan lil aalamin', which can go in harmony with the spirit of nationalism and internationalism.

Multi-ethnic and multilingual pesantren communities can bring about language contact and bilingualism and multilingualism phenomena. Along with the rapid development of technology, the most popular and extensively used communication tool is used for the interaction on social media, namely Facebook. In the interaction on Facebook, santri community in the Assalaam Islamic Modern Islamic Boarding School come from various regions in Indonesia that surely have a variety of languages. Indonesian is the first language of instruction used for everyday social interactions in the boarding school. Students who live in boarding schools will be able to influence the variety of languages such as English, Arabic, Javanese, and other regional languages. The choice of codes is evident in the communication used by the pesantren community, such as social interaction between ustazah and santri, between ustaz and santri, and among the students in the pesantren. The santri community in the Assalaam Islamic Modern Pesantren uses Facebook to impart information, and thus the users' master more than one language, for example, the use of slang in the conversation among santri; the use of multilingual in the social interaction, such as code switching English and Arabic, or Indonesian and English. For example: lemon, it means language month.

\section{MATERIALS AND METHOD}

\subsection{The ChOICE OF CODES IN SOCIOLINGUistics PeRSPECTIVE}

Sociolinguistics is a study of science because it discusses choices in the use of language codes. Code choice is a situation where a linguist is involved in a bilingual interaction. Bilingualism is the use of two or more languages by someone or by a society. There are three types of code choices commonly known in the study of Sociolinguistics. The first type is called code switching. Code is a neutral term that can refer to language, dialect, sociolect, or various languages. The second type of language choice is 
code mixing. The term code mixing is similar to what was once called interference. In other words, in code mixing the speaker inserts some other language elements when using a particular language. Elements borrowed from other languages can be words, phrases, or clauses. The third type of language choice is variation in the same language (variation within the same language). A single variation of language (variations in the same language) usually requires speakers to choose which variety to use in certain situations. The use of variations in the same language is also employed to avoid language errors.

\subsection{FАСЕВООК}

Facebook is one of the online media that is widely used by teenagers in Indonesia. Facebook was founded by Mark E. Zuckeberg in 2004 and began its operations in September 2012, making it available for use by Facebook users around the world for communication. The users are required to register themselves before using Facebook to get a personal account containing profiles, homepage, group, and other facilities offered by Facebook. Along with the development of advanced science and technology, Facebook users can create profiles that include photos and other important information, so people around the world need to be aware of the communication facility which enables others to find themselves. They can interact socially with a list of Facebook friends they have via message or public through chat.

In addition, they can create groups and pages. Up until now, the features on Facebook have undergone various changes and many facilities that support communication interaction have been made operative. One example is the 'wall' that can be used as a place to send messages to other Facebook users to read. In addition, there is a "status" feature where Facebook users are allowed to write down any activities going on around them and publish their existence including what they are thinking. Of course this will invite various interpretations and comments from readers to provide responses or emoticons. Likewise, the Facebook features also come with a 'Note' on which Facebook users can document their writing and share things with their friends or tag friends in the note. Interestingly, Facebook is equipped with photo facilities, so Facebook users can upload photos and store photos with an unlimited number. This has explained why social media like Facebook has the highest rating and is still much in demand by teenagers and adults for communication.

\subsection{MeThodologY}

The present research delves into santri choice of codes when involved in communication on social media. The study is a qualitative in nature, with sociolinguistic approach. Qualitative approach operative in the study includes several phases, including data collection, analysis, interpretation, and writing report, which is different to traditional qualitative approaches. The form of codes under investigation is those used by students when interacting on Facebook in their boarding school environment. The data collected in this study are naturally found in speech events on Facebook. To support data collection, observation, notes, and interviews are also put at work. Data analysis deploys speech component analysis. In addition, the researchers also employ qualitative ethnographic methods.

\section{RESULTS AND DISCUSSION}

The results and discussion on Facebook communication generate a portrait of choice of language codes used by students as follows.

\subsection{INDONESIAN}

Indonesian is usually used in the interaction of official communication in the santri community. But in reality, Indonesian is not only used in official forums but is also used in informal forums. This is the reason why the communication using Indonesian in both formal and informal settings is deemed imperative to facilitate communication, regardless of the language background of speech interlocutors. Because of the influence of information technology, the students in Assalaam Islamic Modern Pesantren prefer to use Indonesian language, used in daily communication interactions. Below is the use of Indonesian language by the students in interactions on social media (Facebook) as follows.

Data 1

Okty Vyta membagikan kiriman.

Santriwati juga bisa berkreasi...

Panggung semegah dan acara yg spektakuler ini hampir sepenuhnya kerja mereka... 
Gak mau kalah sama yg santriwan...

Mereka srikandi sholehah yang bisa sekuat pandawa....

Speeches on data [1] occurred on the Facebook page of the Assalaam Islamic Modern Pesantren. Data [1] includes using informal Indonesian. This is marked by the word gak, which means no in English. In addition, there is a code mixing in English as a spectacular word and mixed Arabic code on the word sholehah. The topic of discussion in the Facebook conversation was the activity of students at the Islamic Modern Assalaam Islamic Boarding School in an event named Mahakarya Santri.

Data 2

\section{Ppmi Assalaam}

Alhamdulillah di pagi yang cerah ini, agenda kegiatan yang ada di PPMI Assalaam adalah kegiatan ta'aruf santri baru dengan didampingi para pengasuh baik dari unit sekolah maupun unit kesantrian. Diharapkan dengan kegiatan ini anak dapat mulai bersosialisasi dengan teman baru maupun dengan para pengasuh uatdz/ustdzh, mulai beradaptasi dengan lingkungan pondok dan juga kegiatan kegiatan yang ada.

In data [2], the students used Indonesian language code when interacting on Facebook. The topic of the discussion was ta'aruf (introduction) at Assalaam Islamic Modern Pesantren. The Indonesian language code was used in formal and informal situations. This was used to interact in order to facilitate communication among various languages and different ethnicities.

\subsection{ARABic LANGUAGE}

Tangible Arabic code was a dominant foreign language code used in internal social interaction within Assalam Modern Islamic Boarding School. This was possible because in the pesantren environment, students had to use Arabic to interact communication. The choice of Arabic code did not occur in a single language form. Hereunder are examples of speeches from students who used Arabic in interacting on Facebook.

Data 3

Ppmi Assalaam

Ta'aruf Santri PPMI Assalaam

\#H3

Ahmad Riyadi Rohmat Full Maa Syaa Alloh. Barokallohu fiikum

Data 4

Ppmi Assalaam

Ahlan wa sahlan wali santri dan santri baru PPMI Assalaam

In data [3] and [4], Arabic language is used for conversations on Facebook. Arabic is the main language used as a means of communication between students, between religious teachers in Islamic boarding schools, and during studying the Yellow book and the Qur'an. The topic of above conversation was the introduction of new santri and welcoming new students. The intensity in using Arabic was quite high in Assalaam Islamic Modern Pesantren because the pesantren required its students to communicate in Arabic.

\subsection{ENGLISH}

The foreign language that is also commonly used by the santri community in Assalaam Islamic Modern Pesantren was English. The use of English in communication among students is more limited, compared to Arabic language. The choice of the English codes also did not occur in a single form of code. In daily communication, the use of the English code was limited as a means of supporting code mixing. The use of the English code usually happened to speakers who had extensive knowledge and were educated. The use of English usually occured because these words were terms commonly used in the conversation on Facebook as follows.

Data 5

Minuk Inuk

Out bound Ppmi Assalaam in TAHURA.

Data 6

Ni'mah Nur Fajarini Thanks a lot for all nice thum 
Data [5] and [6] were spoken by santri in interactions on Facebook. The English used in this context involved popular words like out bound and thanks a lot for all nice thum. Assalaam Islamic Boarding School has a vision and missions aimed at international stage, so English was often used by students in their social interaction.

\subsection{JAVANESE LANGUAGE}

Javanese is one of the regional languages with the highest number of speakers compared to other regional languages in Indonesia. Javanese language is the mother language of Javanese people living in Central Java Province and Yogyakarta Special Region (DIY), and East Java. Students who live in Assalaam Modern Islamic Boarding School use Javanese in social interaction, particularly when they are intimate with their interlocutors. This is also found in online media (facebook) using the Java language as follows.

\section{Data 7}

nunggu sahabat disamping pos satpam itu sesuatu.

kanap...?

kepanasen iya... otal atil koyo cah ilang iyo...

senggol sak kemenge mas suprayogi di Ppmi Assalaam

Melati Kristi Mampir mas...

Shoffa Shofriana Lahhh......tenan pora kui mas Iwan Ga Fals

Data [7] is related to the speech of the santri community on social media (Facebook). In the speech there are two codes used, namely Indonesian: nunggu sahabat disamping pos satpam itu sesuatu. kanap? In addition, Javanese was also operative, as in kepanasen iya... otal atil koyo cah ilang iyo...senggol sak kemenge mas suprayogi. Obviously, that code switching from Indonesian into Javanese occurs. The use of the Javanese language in Assalaam Islamic Modern Pesantren did not always take the form of a single variation because in the school there was a rule prohibiting santri are to use regional languages (Javanese). This was due to different ethnic backgrounds, but students continued to violate the rule by using Javanese when they were familiar with their friends from Java.

\subsection{DisCUSSION}

This research, focusing on the students' choice of codes in communication in online media, has some commonalities with other studies. Studies related to language choices have been conducted by Ma'alip [8]. The results of his research illustrate that Malay and English are the choices among users of social pages followed by Chinese, Indian, and other languages. Fahmee \& Fung [9] examines the choice of languages in the online communication of Maldivian professional communities in family, friendship, and employment context. The results show that Dhivehi is a unique Indo-Aryan language used in exclusive conversations in Maldives, along with English as a second language.

The comparison among abovementioned studies has concluded that this study explains the choice of language codes often used in communicating on Facebook, which includes Indonesian, Arabic, English, and Javanese. The use of Indonesian language is more dominant because it is a daily language of instruction in Assalaam Islamic Modern Pesantren. The use of the Javanese language is still preserved in school.

\section{CONCLUSION}

As a boarding school that uses a variety of languages/language variations when communicating on Facebook for the santri, the choice of codes in choosing the right language variation when communicating has been prevalent. Indonesian is the dominant language used for communication on Facebook because the students come from various regions in Indonesia. This is to facilitate communication. Arabic is an obligatory language for students because Arabic is one of the Muslim identity. In addition to Arabic, English is also used. English as an international language must be mastered by students to communicate with people from different parts of the globe. With respect to Javanese language, the students also use casual Javanese language to communicate on Facebook because they are already familiar with their friends. This indicates that Assalaam Islamic Modern Pesantren still maintains regional languages (Javanese) in the midst of modernization. 


\section{REFERENCES}

Dhofier, Z. 2011. Tradisi Pesantren. Jakarta: LP3ES.

Fishman, Joshua A 1975. Sociolingustics: A brief Introduction. Massacssetts, Rowley Publisher.

Mardikantoro, H.B. 2017. Samin Kajian Sosiolinguistik. Yogyakarta: Penerbit Forum.

Sumarsono and Paina. 2002. Sosiolinguistik, Yogyakarta: Sabda.

Cresswell, J.W. 2009. Research Design. United States America: SAGE Publication Inc.

Hymes, D. 1974. Foundations in Sociolinguistics: An Ethnographic Approach. Philadelphia: University of Pennsylvania Press.

Spreadly, J.P. 1980. Participant Observation. New York, Holt, Rinehart, and Winston,

Ma'alip, S. Pemilihan Bahasa Dalam Komunikasi Di Laman Sosial. Jurnal Komunikasi 31(2) (2015) 231-246

Fahmee, F., \& Fung, Y. M. Language choice in online written communication among Maldivian professionals. 3L: Language, Linguistics, Literature, 22(2) (2016) 49-66. 
